\title{
Nitric Oxide Modulates HCN Channels in Magnocellular Neurons of the Supraoptic Nucleus of Rats by an S-Nitrosylation-Dependent Mechanism
}

\author{
๑Delina Pires da Silva, ${ }^{1}$ Davi José de Almeida Moraes, ${ }^{1}$ André de Souza Mecawi, ${ }^{2}$ José Antunes Rodrigues, ${ }^{1}$ \\ and $\odot$ Wamberto Antonio Varanda ${ }^{1}$ \\ ${ }^{1}$ Department of Physiology, Ribeirão Preto Medical School, University of São Paulo, 14049-900 Ribeirão Preto, São Paulo, Brazil, and ²Department of \\ Physiological Sciences, Biology Institute, Federal Rural University of Rio de Janeiro, 23890-000, Seropédica, Rio de Janeiro, Brazil
}

The control of the excitability in magnocellular neurosecretory cells (MNCs) of the supraoptic nucleus has been attributed mainly to synaptic inputs from circunventricular organs. However, nitric oxide (NO), a gaseous messenger produced in this nucleus during isotonic and short-term hypertonic conditions, is an example of a modulator that can act directly on MNCs to modulate their firing rate. NO inhibits the electrical excitability of MNCs, leading to a decrease in the release of vasopressin and oxytocin. Although the effects of NO on MNCs are well established, the mechanism by which this gas produces its effect is, so far, unknown. Because NO acts independently of synaptic inputs, we hypothesized that ion channels present in MNCs are the targets of NO. To investigate this hypothesis, we used the patch-clamp technique in vitro and in situ to measure currents carried by hyperpolarization-activated and nucleotide-gated cation (HCN) channels and establish their role in determining the electrical excitability of MNCs in rats. Our results show that blockade of HCN channels by ZD7288 decreases MNC firing rate with significant consequences on the release of OT and VP, measured by radioimmunoassay. NO induced a significant reduction in HCN currents by binding to cysteine residues and forming S-nitrosothiol complexes. These findings shed new light on the mechanisms that control the electrical excitability of MNCs via the nitrergic system and strengthen the importance of HCN channels in the control of hydroelectrolyte homeostasis.

Key words: electrolyte homeostasis; electrophysiology; HCN channels; magnocellular neurons; nitric oxide; S-nitrosylation

Significance Statement

Cells in our organism live in a liquid environment whose composition and osmolality are maintained within tight limits. Magnocellular neurons (MNCs) of the supra optic nucleus can sense osmolality and control the synthesis and secretion of vasopressin (VP) and oxytocin (OT) by the neurohypophysis. OT and VP act on the kidneys controlling the excretion of water and sodium to maintain homeostasis. Here we combined electrophysiology, molecular biology, and radioimmunoassay to show that the electrical activity of MNCs can be controlled by nitric oxide (NO), a gaseous messenger. NO reacts with cysteine residues (S-nitrosylation) on hyperpolarization-activated and nucleotide-gated cation channels decreasing the firing rate of MNCs and the consequent secretion of VP and OT.

\section{Introduction}

Maintenance of hydroelectrolyte homeostasis requires complex interactions between peripheral and CNS circuits in several

\footnotetext{
Received May 15, 2016; revised Aug. 23, 2016; accepted Sept. 14, 2016.

Author contributions: M.P.d.S. and W.A.V. designed research; M.P.d.S., D.J.d.A.M., A.d.S.M., and J.A.R. performed research; M.P.d.S. and W.A.V. analyzed data; M.P.d.S. and W.A.V. wrote the paper.

M.P.d.S. was supported by Coordenação de Aperfeiçoamento de Pessoal de Nível Superior fellowship. The laboratory of W.A.V. was supported by Fundacao de Amparo a Pesquisa do Estado de Sao Paulo Grant 2012/19750-7. D.J.d.A.M. was supported by Fundacao de Amparo a Pesquisa do Estado de Sao Paulo Grant 2013/10484-5.

The authors declare no competing financial interests.

Correspondence should be addressed to Dr. Melina Pires da Silva, Department of Physiology, School of Medicine of Ribeirão Preto, University of São Paulo, Av. Bandeirantes, 3900, 14049-900, Ribeirão Preto, São Paulo, Brazil. E-mail:melina@rfi.fmrp.usp.br.
}

mammalian species. The central control of hydroelectrolyte balance involves highly organized hypothalamic structures that operate to maintain the extracellular fluid osmolality within tight limits. Among these structures, the hypothalamic supraoptic nucleus (SON), composed of magnocellular neurosecretory cells (MNCs), plays a critical role in the synthesis and secretion of vasopressin (VP) and oxytocin (OT). These neuropeptides are involved in several processes, including memory, vasoconstriction, reproduction, and prevention of osmotic stress via renal control of sodium and water reabsorption (Poulain et al., 1977; 
Antunes-Rodrigues et al., 2004). Their release is directly correlated with MNC firing rate.

Although the control of MNC electrical excitability can be influenced by synaptic inputs (Bourque, 2008), local modulators have been shown to directly interfere in the final responses of these cells (Ruginsk et al., 2015). Indeed, previous reports from our group (Ventura et al., 2008; da Silva et al., 2013) and others (Ventura et al., 2005; Coletti et al., 2015; Reis et al., 2015) indicate the participation of gaseous signaling molecules in the control of MNC excitability and neurohypophyseal secretion, both under physiological conditions and during short-term increases in plasma osmolality. One of these gaseous messengers is nitric oxide (NO). NO decreases MNC excitability and the release of neuropeptides (Ventura et al., 2005; Reis et al., 2010), although the corresponding underlying mechanism remains unknown.

Members of the cyclic nucleotide-gated family of ion channels, such as the hyperpolarization-activated and nucleotide-gated cation (HCN) channel, are strong candidates for controlling MNC excitability (Ghamari-Langroudi and Bourque, 2000). First described in the heart (DiFrancesco, 1993) and later in the CNS (Pape, 1996), $\mathrm{HCN}$ channels are involved in numerous intrinsic neuronal functions, such as regulation of resting membrane potential, spontaneous firing in pacemaker cells, synaptic transmission, and regulation of membrane resistance (Kase and Imoto, 2012). Four subtypes of HCN channels (HCN1-HCN4) are expressed in mammals with $\sim 60 \%$ molecular identity between them. Once open, these channels allow the flow of a cationic current, termed $\mathrm{I}_{\mathrm{h}}$, carried by both $\mathrm{Na}^{+}$ and $\mathrm{K}^{+}$with permeability ratio $\frac{P_{\mathrm{Na}^{+}}}{P_{\mathrm{K}^{+}}}=0.2$ to 0.4 (Pape, 1996). In addition to being voltage-dependent, $\mathrm{HCN}$ channels are also known to be controlled by cAMP and cGMP (Biel et al., 2009). The latter is also the major second messenger used by NO (Denninger and Marletta, 1999; Matulef and Zagotta, 2003; Zagotta et al., 2003). Based on this evidence, the present study aimed to analyze the mechanisms by which $\mathrm{NO}$ acts on $\mathrm{HCN}$ channels and influences the intrinsic activity of MNCs. We demonstrated that blockade of HCN channels results in important changes in MNC firing frequency, resting membrane potential, and peptides release into the circulation. Furthermore, NO modulates the intrinsic activity of these channels via a cGMP-independent mechanism involving posttranslational modification of ion channel proteins by oxidation of cysteine residues, a mechanism known as S-nitrosylation.

\section{Materials and Methods}

Ethics. We used male Wistar rats $(80-100 \mathrm{~g})$ to perform all experiments, which were approved by the Ethical Committee on Animal Experimentation of Ribeirão Preto Medical School, University of São Paulo (protocols 064/2010 and 023/2012).

Hypothalamic supraoptic brain slices. Hypothalamic brain slices were obtained as previously described (da Silva et al., 2013). In short, Wistar rats $(100-120 \mathrm{~g})$ were killed by decapitation, and the brain was quickly removed from the skull and placed in an ice-cold $\left(0^{\circ} \mathrm{C}\right)$ ACSF solution containing the following (in $\mathrm{mm}$ ): $121 \mathrm{NaCl}, 2.5 \mathrm{KCl}, 25$ glucose, 26 $\mathrm{NaHCO}_{3}, 2 \mathrm{CaCl}_{2}, 1 \mathrm{MgCl}_{2}$, saturated with carbogen $\left(95 \% \mathrm{O}_{2} / 5 \% \mathrm{CO}_{2}\right)$, with pH 7.35, osmolality $310 \mathrm{mosm} / \mathrm{kg} \mathrm{H}_{2} \mathrm{O}$.

A block of tissue containing the hypothalamus was placed on the platform of a Vibratome (VT 1200, Leica), and coronal slices (230- $\mu \mathrm{m}-$ thick) containing the SON were obtained. Slices were incubated for 60 min at $36^{\circ} \mathrm{C}$ in modified ACSF with the following composition (in mM): $121 \mathrm{NaCl}, 4 \mathrm{KCl}, 10$ glucose, $26 \mathrm{NaHCO}_{3}, 2 \mathrm{CaCl}_{2}, 1 \mathrm{MgCl}_{2}$, constantly gassed with carbogen, $\mathrm{pH} 7.35$, osmolality $295 \mathrm{mosm} / \mathrm{kg} \mathrm{H}_{2} \mathrm{O}$. A single slice was transferred to the recording chamber placed on the stage of a microscope (Nikon, E-600FN), and neurons were identified using infrared differential contrast optics with images captured by a CCD digital camera (Sensicam qe, Cooke).
Isolation of magnocellular neurons. MNCs were isolated from cylindrical punches made laterally to the optic chiasm in hypothalamic coronal slices (230- $\mu \mathrm{m}$-thick), using a 16 gauge sharpened needle. The tissue fragments containing the SON were washed and incubated in Hanks solution (in mM) as follows: $121 \mathrm{NaCl}, 4 \mathrm{KCl}, 5 \mathrm{NaHCO}_{3}, 10 \mathrm{HEPES}, 10$ glucose (constantly gassed with $100 \%$ oxygen; $\mathrm{pH} 7.35$, osmolality 295 mosm $\left./ \mathrm{kg} \mathrm{H}_{2} \mathrm{O}\right)$ and trypsin $(7 \mathrm{mg} / \mathrm{ml}$, Sigma Chemical) for $30 \mathrm{~min}$ at $37^{\circ} \mathrm{C}$. Then, the tissue fragments were washed again with Hanks solution and incubated for $10 \mathrm{~min}$ with $0.05 \%$ trypsin inhibitor (Sigma Chemical). Subsequently, the solution was substituted with Neurobasal Medium supplemented with 2\% B27 (Serum Free, Invitrogen), $0.5 \mathrm{~mm}$ glutamine, $1 \%$ penicillin and streptomycin, and the cells were gently dispersed by aspiration and flushing with fire-polished Pasteur pipettes with decreasing diameters. The cells were then plated on plastic dishes with glass bottoms, and electrophysiology was performed after $24 \mathrm{~h}$. The OT and/or VP phenotype of the isolated neurons was recognized using single-cell qRT-PCR (for details, see below).

In situ brainstem-hypothalamus preparation. In this set of experiments, we simultaneously measured electrophysiological parameters and hormone release using a precollicularly decerebrated preparation, as originally described by Antunes et al. (2006). Briefly, Wistar rats (100-120 g) were deeply anesthetized with halothane (Itapira), bisected below the fifth rib and decorticated. At this point, anesthesia was terminated. The preparation was transferred to a recording chamber, and a double-lumen catheter was placed into the aortic arch through the left ventricle, for hypothalamus perfusion with ACSF solution containing the following (in mM): $121 \mathrm{NaCl}, 4 \mathrm{KCl}, 10$ glucose, $26 \mathrm{NaHCO}_{3}, 2 \mathrm{CaCl}_{2}, 1 \mathrm{MgCl}_{2}(\mathrm{pH}$ 7.35 , osmolality $295 \mathrm{mosm} / \mathrm{kg} \mathrm{H} \mathrm{O}$ ) saturated with $95 \% \mathrm{O}_{2} / 5 \% \mathrm{CO}_{2}$. Ficoll (molecular weight 20,000; 1.25\%) was added as an oncotic agent and vecuronium bromide ( $4 \mu \mathrm{g} / \mathrm{ml}$ Cristália, Itapira) as a muscle relaxant. The superior vena cava was cannulated to collect samples from the hypophyseal circulation for measurement of peptide concentrations by radioimmunoassay (see below).

MNCs intrinsic electrical activity was measured with the blind patchclamp technique in the whole-cell configuration (one neuron per preparation). Biocytin (0.2\%, Invitrogen) was added to the patch pipette solution to label the recorded neurons by immunofluorescence (for details, see below). The micropipettes were mounted on a micromanipulator (MHW-3; Narishige) and positioned onto the dorsal surface of the hypothalamus under visual control by a binocular microscope (Seiler Precision Microscope, SSI-202/402).

Infusion of ZD7288 (30 $\mu \mathrm{M})$ into the SON was made through the inner aperture ( $1 \mathrm{~mm}$ in diameter) of a perforated ring secured on the hypothalamus dorsal surface and placed directly above the SON neurons. This allowed a local bath-like application of drugs, which diffused to the SON neurons within 3-5 min. Infusion of isotonic ACSF was used as a control for ZD7288.

At the end of the experimental procedures, the preparations were perfused with $4 \%$ PFA and the brains were removed and postfixed in $4 \%$ PFA for $2-5 \mathrm{~d}$. Transverse sections ( $40-\mu \mathrm{m}$-thick) were cut through the SON with a vibrating microtome (Leica), collected into a cryoprotectant solution, and stored at $-20^{\circ} \mathrm{C}$ for further processing. The immunofluorescence was performed with free-floating sections. After three PBS (0.1 M PBS) washes, the sections were incubated with Alexa-488-conjugated streptavidin (1:1.000; Invitrogen) for $1 \mathrm{~h}$ at room temperature. Slices were washed three times in PBS and mounted with Fluoromount (Sigma-Aldrich) on glass slides. Images were collected on a Leica TCS SP5 confocal microscope equipped with $488 \mathrm{~nm}$ laser line and tunable emission wavelength detection. For each preparation, biocytinpositive neurons were identified and confocal $z$-stacks were sequentially collected.

Whole-cell recordings. Whole-cell recordings of both in vitro and in situ preparation were done using borosilicate glass micropipettes with resistance ranging from 4 to $5 \mathrm{M} \Omega$ when filled with the following pipette solution (in mM): 140 potassium gluconate, $10 \mathrm{KCl}, 0.3 \mathrm{CaCl}_{2}, 1.0 \mathrm{MgCl}_{2}$, 10 HEPES, 1.0 EGTA, $2.0 \mathrm{Na}$-ATP, $0.25 \mathrm{Na}-\mathrm{GTP}, 0.2 \mathrm{~mm}$ cAMP, pH adjusted to 7.35 with $\mathrm{KOH}$ and osmolality ranging from 285 to 295 mosm $/ \mathrm{kg} \mathrm{H}_{2} \mathrm{O}$. Milli Q water used to prepare pipette solution was treated overnight with diethylpyrocarbonate (Sigma-Aldrich) for subsequent 
A

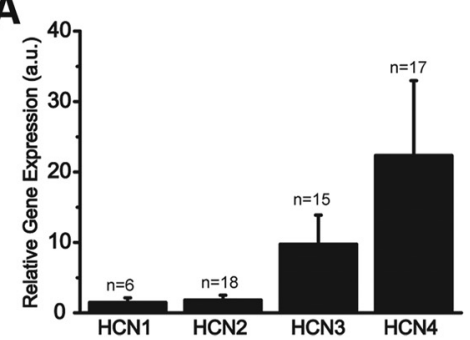

B

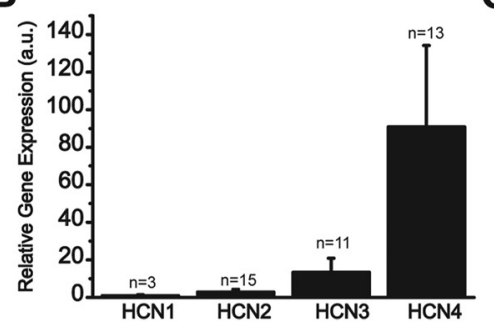

C

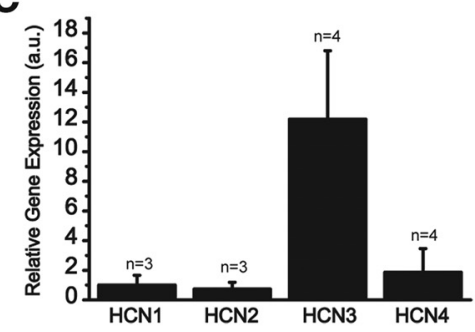

Figure 1. mRNA expression of HCN channel isoforms. Expression of HCN channels in the supraoptic nucleus was performed using single-cell qRT-PCR. The relative quantification of HCN gene expression was done using the $2^{-\Delta \Delta C T}$ method, and the $\beta$-actin housekeeping gene was used as internal control. The expression of HCN2, HCN3, and HCN4 is shown in relation to HCN1 expression level. All isoforms were expressed in the MNCs $(\boldsymbol{A})$ with HCN3 and HCN4 showing the highest expression levels, but not significantly different from the other isoforms. $\boldsymbol{B}, \boldsymbol{C}$, HCN expression in vasopressinergic and oxytocinergic neurons, respectively. $n$ indicates the number of cells tested.

single-cell qRT-PCR procedures. The junction potential between pipette and bath solution was calculated using Clampex (Molecular Devices), and the value $(-15 \mathrm{mV})$ was subtracted from baseline during data analysis. Voltages or currents were measured at room temperature using an Axon 200B patch-clamp amplifier (Molecular Devices), filtered at $2 \mathrm{kHz}$, and digitized at $10 \mathrm{kHz}$ with a Digidata 1440A (Molecular Devices) controlled by Clamplex (pClamp 10, Molecular Devices). Capacitance and access resistance (compensated by $40 \%-60 \%$ when necessary) were electronically measured using the amplifier settings. $\mathrm{I}_{\mathrm{h}}$ currents were evoked by $3 \mathrm{~s}$ hyperpolarizing voltage pulses ranging from -50 to $-120 \mathrm{mV}$ (in $-10 \mathrm{mV}$ steps) every $8 \mathrm{~s}$, as described previously (GhamariLangroudi and Bourque, 2000). To avoid synaptic effects on $\mathrm{I}_{\mathrm{h}}$ currents and other conductances, all measurements reported in this paper were made in the presence of synaptic blockers (glutamate antagonists $=10$ $\mu \mathrm{M}$ CNQX and $30 \mu \mathrm{M}$ DL-AP5, GABA antagonist $=30 \mu \mathrm{m}$ picrotoxin) and potassium channels blockers (1 mM tetraethylammonium chloride and $1 \mathrm{~mm} 4$-aminopiridine).

For acute hypertonic stimulation, $35 \mathrm{~mm}$ mannitol was added to the isotonic ACSF recording solution to obtain $330 \mathrm{mosm} / \mathrm{kg} \mathrm{H}_{2} \mathrm{O}$ as final osmolality. For hypotonic stimulation, $116 \mathrm{~mm} \mathrm{NaCl}$ was used instead of $121 \mathrm{~mm}$, and the final osmolality was $285 \mathrm{mosm} / \mathrm{kg} \mathrm{H} \mathrm{H}_{2} \mathrm{O}$.

Real time qRT-PCR. Single-cell qRT-PCR was used for both characterizing HCN channel subtypes expressed in single MNCs and phenotyping the recorded cell. For this purpose, we followed the same procedures described previously (da Silva et al., 2015). In brief, after electrophysiological recordings, the cytoplasm of each neuron, diluted into the pipette solution, was collected for mRNA reverse transcription (High Capacity cDNA Reverse Transcription Kit, Invitrogen). mRNA reverse transcription was performed before a preamplification step, using the TaqMan PreAmp Master Mix Kit (Invitrogen) and the following hydrolysis probes: Rn00564446_g1 (vasopressin), Rn00566449_ml (oxytocin), Rn00670384_ml (HCN1), Rn01408572_mh (HCN2), Rn00586666_m1 (HCN3), and Rn00572232_ml (HCN4). $\beta$-Actin was used as an endogenous reference gene (NM_031144.2).

Finally, the reactions for the single-cell RT-PCR were performed in simplex and in triplicate (StepOne Plus System, Applied Biosystems) using the probes described before and a TaqMan Universal PCR Master Mix kit (Invitrogen) according to the manufacturer's recommendations.

Analysis of single-cell qRT-PCR phenotypes. The relative quantification of HCN gene expression was done using the $2^{-\Delta \Delta C T}$ method (Livak and Schmittgen, 2001). However, MNC phenotypes (VP or OT or intermediate) were determined based on the ratio analysis described previously (da Silva et al., 2015) following the principles outlined by Heid et al. (1996). The equation below was used to analyze the results.

$$
\frac{X_{V P}}{X_{O T}}=\frac{\left(1+E_{O T}\right)^{C q_{O T}}}{\left(1+E_{V P}\right)^{C q V P}}
$$

Where $\frac{X_{V P}}{X_{O T}}$ is the ratio of the initial amount of vasopressin cDNA to the initial amount of oxytocin cDNA, $\mathrm{E}_{\mathrm{ot}}$ and $\mathrm{E}_{\mathrm{vp}}$ are the amplification efficiencies for each gene, and $\mathrm{Cq}_{\mathrm{ot}}$ and $\mathrm{Cq}_{\mathrm{vp}}$ are the quantities of oxytocin and vasopressin cDNA in the quantification cycle, respectively.
According to the above protocol, neurons with a ratio $>1$ were considered vasopressinergic, whereas neurons with a ratio $<1$ were considered oxytocinergic. A ratio equal to 1 suggested expression of both peptides and the neuron was classified as intermediate.

Radioimmunoassay. VP and OT were quantified in the effusate collected from the superior vena cava in heparinized tubes during isotonic condition and after hypertonic stimulation, preceded by either ACSF or ZD7288 local infusion. Remaining blood cells were separated from ACSF by centrifugation $\left(20 \mathrm{~min}, 3000 \mathrm{rpm}\right.$ at $4^{\circ} \mathrm{C}$ ) and samples were stored at $-20^{\circ} \mathrm{C}$ until hormone extraction and radioimmunoassay procedures. The effusate was treated with acetone and petroleum ether and VP and OT were measured using specific antibodies, rabbit anti-VP-RAS 8103 , 1:120,000, and rabbit anti-OT-HIC8152, 1:80,000 (Peninsula Laboratories). The assay sensitivity was $0.1 \mathrm{pg} / \mathrm{ml}$ for both hormones and interassay variability were $1.8 \%$ for OT and $1.4 \%$ for VP.

Drugs. L-Arginine monohydrochloride, D-arginine monohydrochloride, $\mathrm{N}$-nitro-L-arginine methyl ester hydrochloride (L-NAME), $\mathrm{N}$-nitro-Darginine methyl ester hydrochloride (D-NAME), DL-2-amino-5-phosphonovaleric acid (DL-AP5), and tetraethylammonium chloride (TEA), 4-aminopiridine (4-AP) were purchased from Sigma Chemical, and CNQX, picrotoxin, $\mathrm{N}$-ethylmaleimide (NEM), and ZD7288 were purchased from Tocris Bioscience.

Analysis and statistics. $\mathrm{I}_{\mathrm{h}}$ currents were isolated by digital subtraction of traces recorded in the absence and presence of ZD7288, a HCN channel blocker, to eliminate other time- and voltage-dependent currents. All electrophysiological data were analyzed off-line using the Clampfit (Molecular Devices) and Origin 8 (Origin Laboratory) programs. Averaged data are expressed as mean \pm SEM and compared using Student's paired or unpaired $t$ test, and repeated-measures ANOVA followed by Bonferroni post hoc test using Prism 6 (GraphPad Software). Values of $p \leq 0.05$ were considered statistically significant differences.

\section{Results}

HCN channels and the excitability of MNCs

Single-cell qRT-PCR experiments showed that VP- and OTsecreting cells express all types of HCN channel isoforms. Although HCN3 and HCN4 had higher levels of expression in all tested cells, they are not statistically different from each other (Fig. 1A). No differential expression was observed when comparing VP and OT neurons (Fig. $1 B, C$ ). The role played by HCN channels in determining the electrical activity of MNCs is shown in Figure 2. ZD7288 (30 $\mu \mathrm{M})$, a known $\mathrm{I}_{\mathrm{h}}$ current blocker (Harris and Constanti, 1995), induced a decrease in MNC intrinsic firing frequency (control $=4.3 \pm 0.5 \mathrm{~Hz}$; ZD7288 $=2.7 \pm 0.4 \mathrm{~Hz}, n=$ $12, p<0.05)$. Furthermore, 9 of 12 recorded neurons showed a significant hyperpolarization in the resting membrane potential when treated with ZD7288 in comparison with control cells (Fig. $2 \mathrm{~B}, \mathrm{B1}$; control $=-56.5 \pm 1.1 \mathrm{mV}$ vs $\mathrm{ZD} 7288=-60.6 \pm 1.8 \mathrm{mV}$, $n=9, p<0.05)$. These results indicate that HCN channels determine MNC electrical activity. 
A
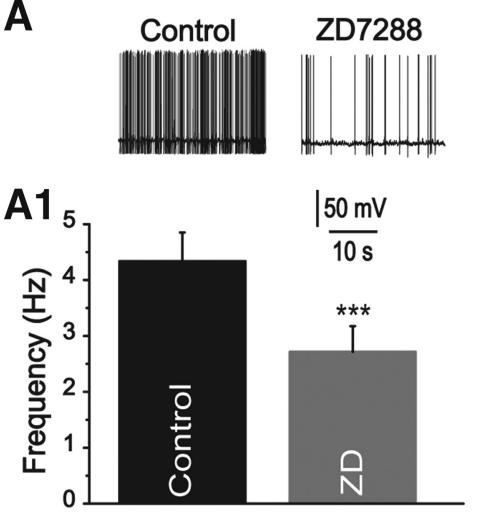

B

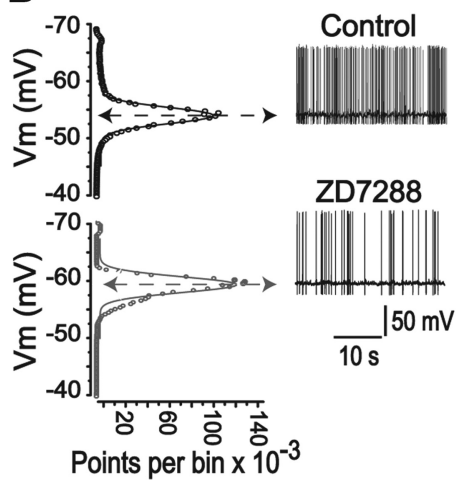

B1

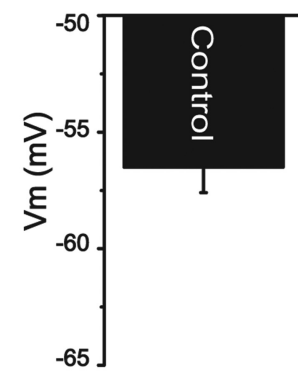

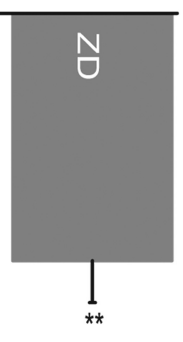

Figure 2. HCN channels are involved in the control of MNC electrical excitability. $A$, Representative traces showing the firing of action potentials of a neuron in control condition and after the superfusion of the cell with $30 \mu \mathrm{mZD7288.A1}$, Mean \pm SEM for 12 neurons recorded in each situation. There is a significant decrease in the MNC firing frequency in the presence of ZD7288 compared with control. B, All-points amplitude histograms of $30 \mathrm{~s}$ data segments of one representative neuron in the control and in the presence of ZD7288. The date were fitted by a Gaussian function with peaks at $-56.5 \pm 1.1 \mathrm{mV}$ for the control and $-60.6 \pm 1.8 \mathrm{mV}$ for $Z D 7288$, representing the values at which neurons spent most of the time in each situation (i.e., the resting membrane potential). A significant hyperpolarization was observed in 9 of 12 cells. B1, Mean values are shown. ${ }^{* *} p<0.005$ (paired Student's $t$ test). ${ }^{* * *} p<0.001$ (paired Student's $t$ test).

A
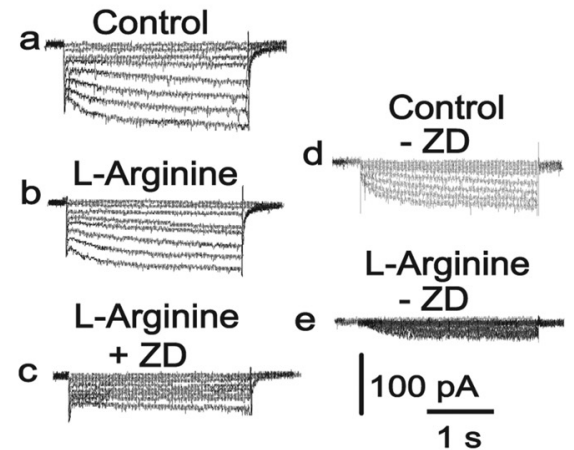

B

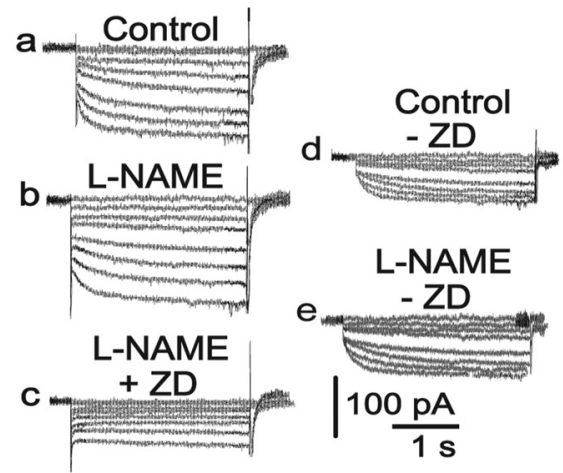

A1

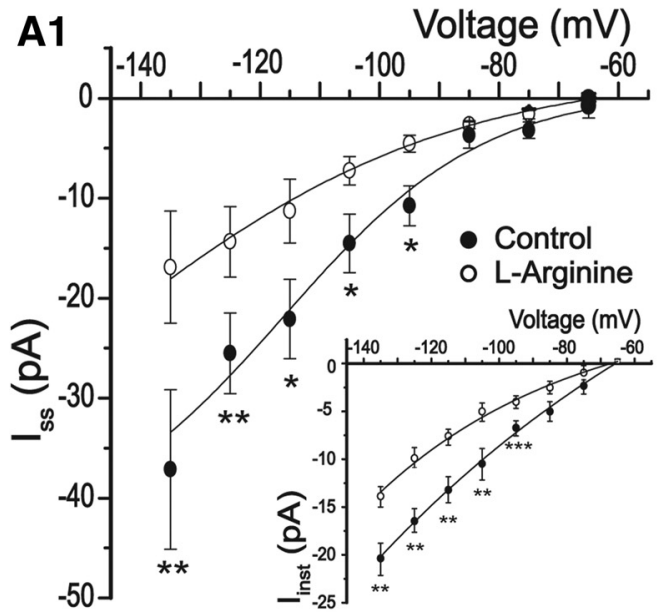

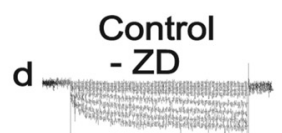

B1

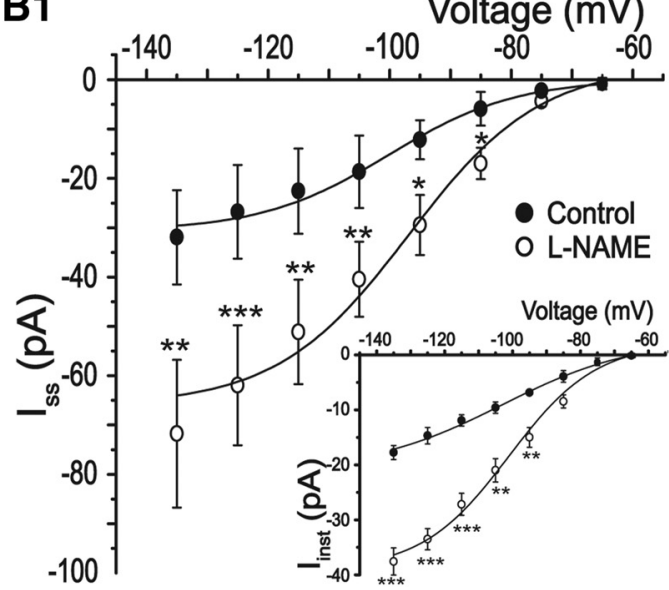

Figure 3. NO inhibits hyperpolarization-activated cation currents. Left, $A, \boldsymbol{B}$, Typical current traces evoked by 3 s voltage pulses ranging from -65 to $-135 \mathrm{mV}$ in the control condition (a), after 10 min of exposure to $500 \mu \mathrm{m} \mathrm{L}$-arginine or $100 \mu \mathrm{m} \mathrm{L-NAME}(\boldsymbol{b})$, and after 10 min of exposure to $30 \mu \mathrm{m}$ ZD7288 (c). Steady-state $\left(\mathrm{I}_{\mathrm{ss}}\right)$ and instantaneous $\left(\mathrm{I}_{\text {inst }}\right) \mathrm{I}_{\mathrm{h}}$ currents were obtained by digitally

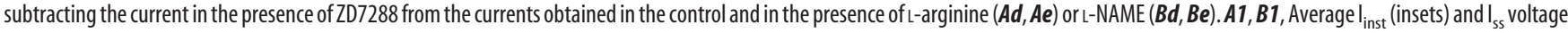
relationships under control condition (filled circles) and in the presence of L-arginine or L-NAME (open circles), respectively. ${ }^{*} p<0.05$ (paired Student's t test). ${ }^{* *} p<0.005$ (paired Student's $t$ test). ${ }^{* * *} p<0.001$ (paired Student's $t$ test).

\section{Nitrergic modulation of $\mathrm{HCN}$ channels}

Because HCN channels seem to be involved in MNC excitability, we performed experiments to analyze whether the nitrergic modulation occurred through a direct action on $\mathrm{I}_{\mathrm{h}}$ currents. Results shown in Figure $3 A, B$ demonstrate that $500 \mu \mathrm{M} \mathrm{L}$-arginine, an NO substrate, significantly decreased instantaneous $\mathrm{I}_{\mathrm{h}}$ currents $(-20.4 \pm 1 \mathrm{pA}$ vs $-13.7 \pm 1 \mathrm{pA}$; at $-135 \mathrm{mV})$, as well as steady- state current amplitude $(-37.1 \pm 7.9 \mathrm{pA}$ vs $-16.9 \pm 4.2 \mathrm{pA}$; measured at $-135 \mathrm{mV}, n=9$; $p<0.05)$. In contrast, $100 \mu \mathrm{M}$ L-NAME (NO synthase inhibitor) significantly increased instantaneous $\mathrm{I}_{\mathrm{h}}(-17.7 \pm 1 \mathrm{pA}$ vs $-37.5 \pm 2 \mathrm{pA}$, measured at -135 $\mathrm{mV}$ ) and steady-state $\mathrm{I}_{\mathrm{h}}$ current (from $-26.5 \pm 9 \mathrm{pA}$ in control to $-71.7 \pm 14 \mathrm{pA}$; measured at $-135 \mathrm{mV}, n=6 ; p<0.05$ ) pointing to an endogenous action of NO on HCN channels. The specificity 
A
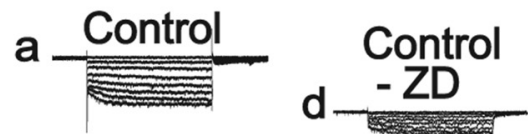

b D-Arginine

D-Arginine
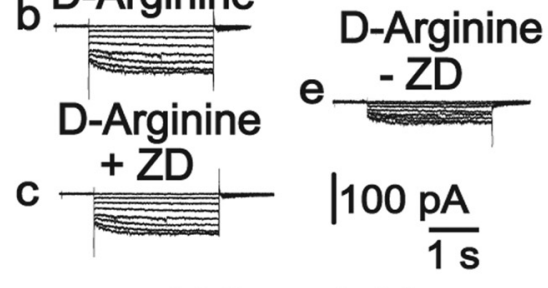

Voltage $(\mathrm{mV})$

A1

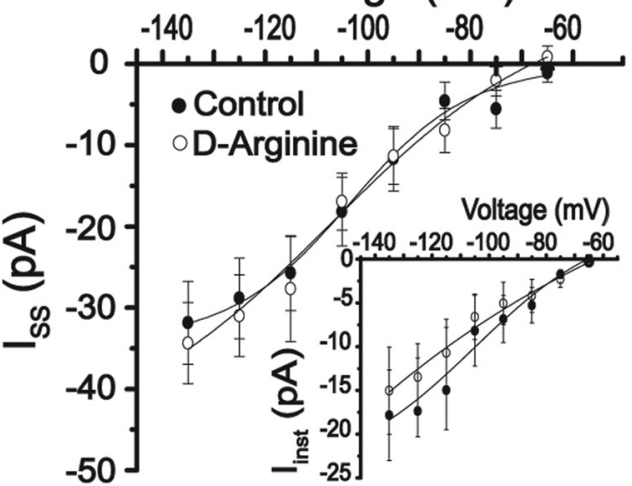

C
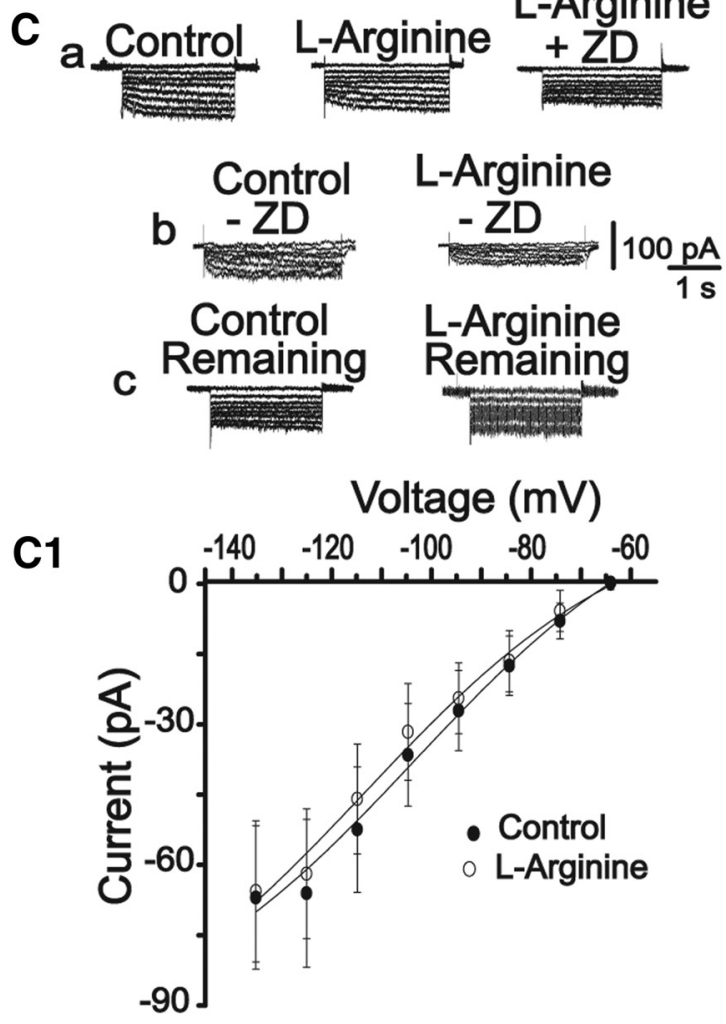

B
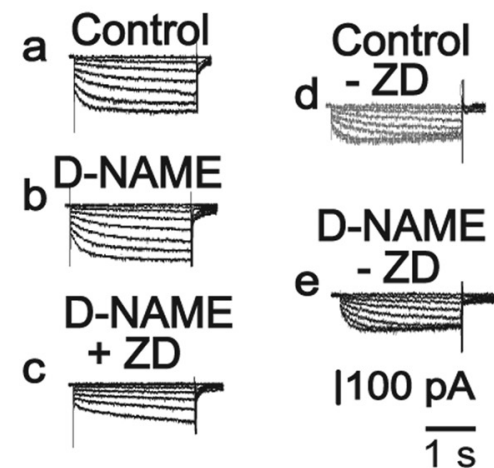

B1
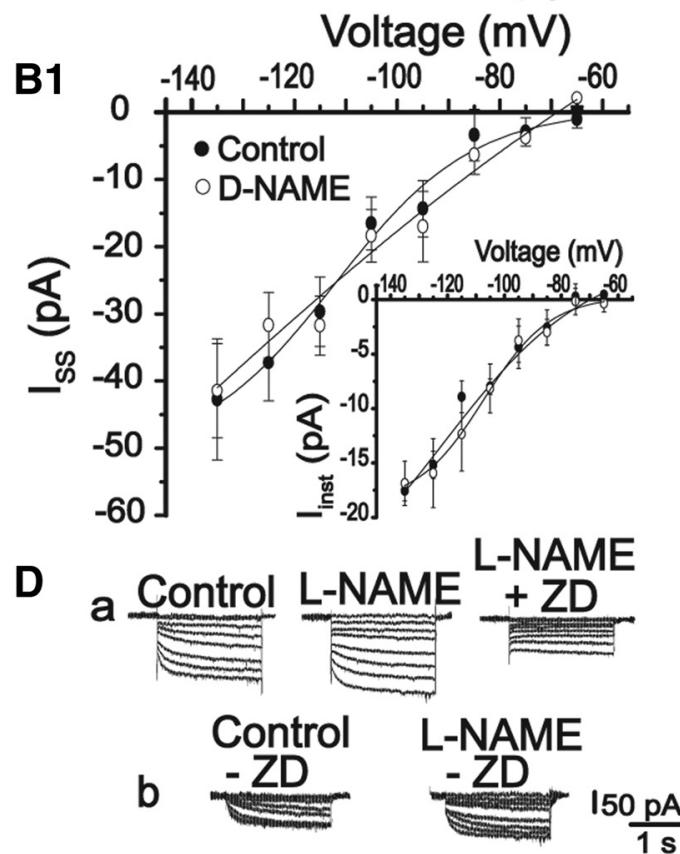

Control L-NAME c Remaining Remaining

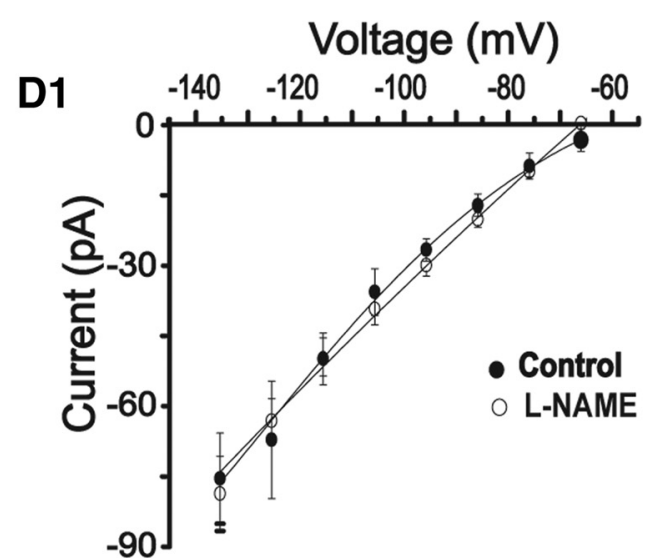

Figure 4. Inactive isomers do not affect $\mathrm{I}_{\mathrm{h}}$ currents. $\boldsymbol{A}, \boldsymbol{B}$, Typical traces of instantaneous $\left(\mathrm{l}_{\text {inst }}\right)$ and steady-state $\left(\mathrm{I}_{\mathrm{ss}}\right) \mathrm{I}_{\mathrm{h}}$ currents under control condition $(\boldsymbol{a})$, after 10 min of exposure to $500 \mu \mathrm{M}$ D-arginine or $100 \mu \mathrm{M}$ D-NAME $(\boldsymbol{b})$, followed by 10 min exposure to ZD7288 $30 \mu \mathrm{M}(\boldsymbol{c})$. The currents, obtained by the subtraction method, are illustrated in $\boldsymbol{d}$ and $\boldsymbol{e}$ for each situation. $\boldsymbol{A 1}, \boldsymbol{B 1}$, The corresponding $I_{\text {inst }}$ (insets) and $I_{\text {ss }} I-V$ relationships for each situation. No significant statistical differences were observed in the presence of the inactive isomer, $D$-arginine $\left(I_{\text {inst }}=-17.5 \pm 5 \mathrm{pA}\right.$ vs $-15 \pm 4 \mathrm{pA} ; \mathrm{I}_{\mathrm{ss}}=-31.8 \pm 5 \mathrm{pAvs}-34.3 \pm 5 \mathrm{pA}, n=6$, at $\left.-135 \mathrm{mV}, p>0.05\right)$ or $\mathrm{D}-\operatorname{NAME}\left(\mathrm{I}_{\text {inst }}=-17 \pm 0.9 \mathrm{pAvs} 16.8 \pm 2 \mathrm{pA} ; \mathrm{I}_{\mathrm{ss}}=-42.7 \pm 9 \mathrm{vs}-41.4 \pm 7, n=7\right.$, at $-135 \mathrm{mV}$, $p>0.05) . C, D$, Representative traces of the ZD7288-resistant current (remaining current) activated by voltage pulses as described before under the following conditions: control,ZD7288, ZD +500 $\mu$ m L-arginine, or $100 \mu \mathrm{m} \mathrm{L}$-NAME. $\boldsymbol{C} \boldsymbol{b}, \boldsymbol{D} \boldsymbol{b}$, The ZD-sensitive current (i.e., $\mathrm{I}_{\mathrm{h}}$ ). A second subtraction analysis was performed: $\boldsymbol{C} \boldsymbol{a}, \boldsymbol{C} \boldsymbol{b}$ or $\boldsymbol{D} \boldsymbol{a}, \boldsymbol{D} \boldsymbol{b}$, to obtain a non-ZD-sensitive component, denoted here as remaining current $(\mathbf{C C}, \mathbf{D C}) . \mathbf{C 1}, \mathbf{D 1}$, Average $\mathrm{I}-\mathrm{V}$ relationships for the remaining currents in the control (open circles) and in the presence of $\mathrm{L}$-arginine or L-NAME (filled circles), respectively. No differences were observed in the presence of L-arginine ( $-66 \pm 15 \mathrm{pA} \mathrm{vs}-65 \pm 15 \mathrm{pA}, n=6, p>0.05$ at $-135 \mathrm{mV})$ or L-NAME $(-78 \pm 10 \mathrm{pAvs}-82 \pm 8 \mathrm{pA}, n=6, p>0.05$ at $-135 \mathrm{mV})$. ${ }^{*} p<0.05$ (paired Student's $t$ test). ${ }^{* *} p<0.005$ (paired Student's $t$ test). ${ }^{* * *} p<0.001$ (paired Student's $t$ test). 
A

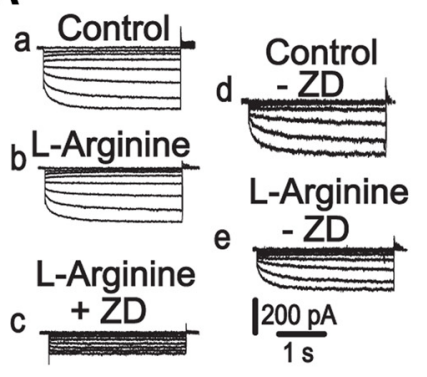

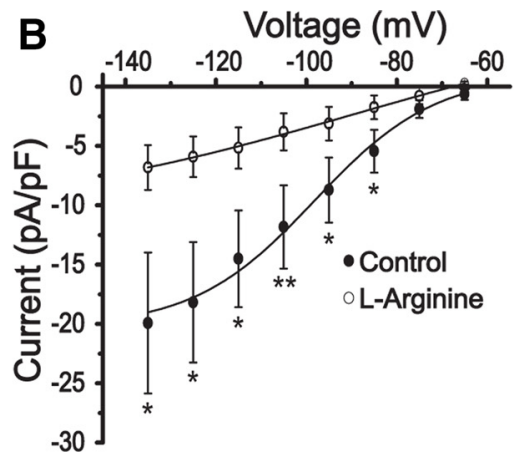

C

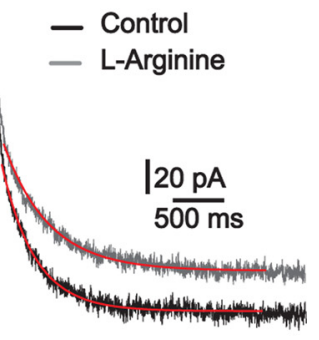

Figure 5. N0 modulates $\mathrm{I}_{\mathrm{h}}$ current in isolated cells. $\boldsymbol{A}$, Representative traces of $\mathrm{I}_{\mathrm{h}}$ currents in an isolated MNC in a control condition ( $\boldsymbol{a}$ ), in the presence of $500 \mu \mathrm{ML}$-arginine ( $\boldsymbol{b}$ ) followed by $Z \mathbf{D D} 7288$ (c). $\boldsymbol{d}, \boldsymbol{e}$, The subtracted currents, $\mathrm{I}_{\mathrm{h}}$. $\boldsymbol{B}$, The $\mathrm{I}-\mathrm{V}$ relationship shows a significant decrease of $\mathrm{I}_{\mathrm{h}}$ current in the presence of $\mathrm{L}$-arginine compared with the control group. $\boldsymbol{C}$, Representative traces of $\mathrm{I}_{\mathrm{h}}$ currents measured in a single neuron at $-135 \mathrm{mV}$ to illustrate the method used to calculate the activation time constant of $\mathrm{I}_{\mathrm{h}}$. A single exponential function was fitted to the data points and calculated accordingly. ${ }^{*} p<0.05$ (paired Student's $t$ test). ${ }^{* *} p<0.005$ (paired Student's $t$ test).

A
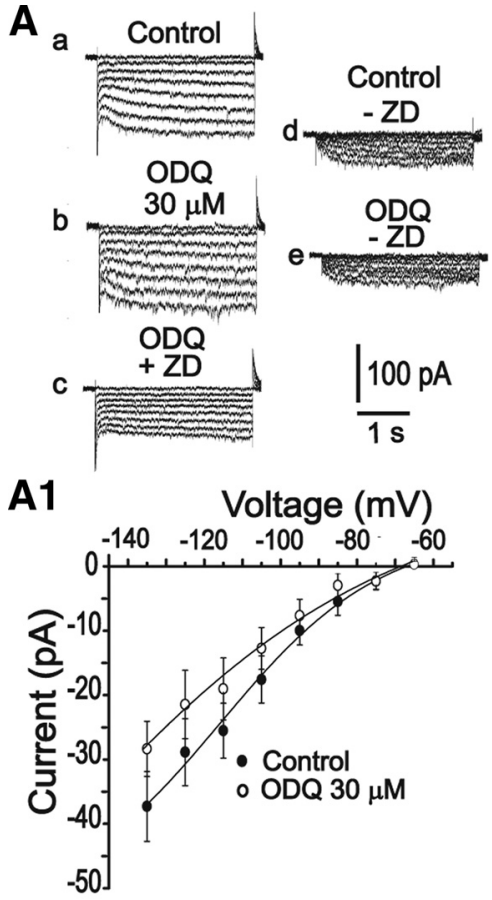

B

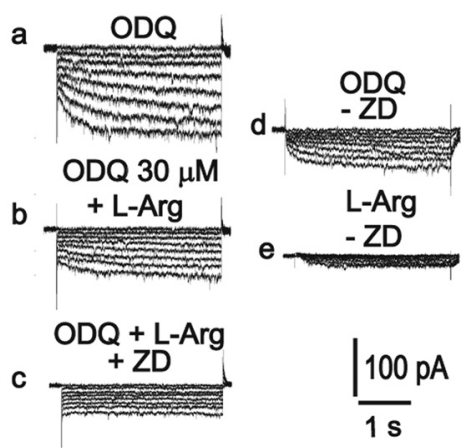

B1

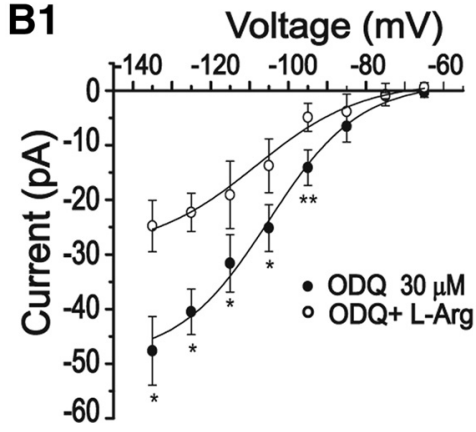

Figure 6. Nitrergic modulation on HCN channels is independent of CGMP. $\boldsymbol{A}, \boldsymbol{B}$, Representative $\mathrm{I}_{\mathrm{h}}$ currents in control, in the presence of ODQ $(30 \mu \mathrm{M}), 0 D Q$ plus L-arginine followed by the specific inhibitor of I ${ }_{h}, Z D 7288(30 \mu \mathrm{M}) . \mathbf{A 1}, \mathbf{B 1}, I-V$ relationships of ZD7288-sensitive currents in the control and in the presence of $30 \mu \mathrm{M} \mathrm{OQD}$. Even in the presence ODQ, L-arginine induced a significant decrease in $\mathrm{I}_{\mathrm{h}}{ }^{*} p<0.05$ (paired Student's $t$ test). ${ }^{* *} p<0.005$ (paired Student's $t$ test).

of NO effects was tested using both inactive isomers and remaining current analysis (Fig. 4).

\section{Nitrergic modulation of $\mathrm{HCN}$ channels in isolated neurons}

Experiments in this section were devised to test the hypothesis that $\mathrm{NO}$ acts directly on MNCs. As shown in Figure $5 A, B$, $\mathrm{L}$-arginine induced the same type of effect observed on slices, decreasing $\mathrm{I}_{\mathrm{h}}$ current amplitude (control $=-19.9 \pm 5.9 \mathrm{pA} / \mathrm{pF}$; $\mathrm{L}$-arginine $=-6.8 \pm 1.9 \mathrm{pA} / \mathrm{pF}, n=8 ; p<0.05$ at $-135 \mathrm{mV})$ and also increased the time constant of activation of the current (Fig. $5 C)(\tau=109 \pm 6.2 \mathrm{~ms}$ in the control and $\tau=167.8 \pm 32.2 \mathrm{~ms}$ with L-arginine, at $-135 \mathrm{mV}, n=8, p<0.05)$. These results clearly show that synaptic connections are not a prerequisite for NO effect on MNCs.

\section{Nitrergic signaling pathway}

Because cGMP is reported to be implicated in the effects of NO (Arnold et al., 1977; Denninger and Marletta, 1999) and HCN channels have a cytoplasmatic binding site for cGMP, we investigated whether the nitrergic modulation of $\mathrm{I}_{\mathrm{h}}$ currents could involve cGMP synthesis. To this end, a selective inhibitorqj of soluble guanylate cyclase (sGC), $\mathrm{H}-(1,2,4)$ oxadiazole $[4,3-\mathrm{a}]$ quinoxalin1-one (ODQ), was used in different concentrations $(3,30$, and $100 \mu \mathrm{M})$. Inhibition of sGC did not change the steady-state value of $I_{h}$ currents in concentrations up to $100 \mu \mathrm{M}(3 \mu \mathrm{M}=$ $-33.3 \pm 7 \mathrm{pA}$ vs $-33 \pm 6 \mathrm{pA}, n=8, p>$ $0.05 ; 30 \mu \mathrm{M}=-30.6 \pm 4 \mathrm{pA}$ vs $-37.2 \pm 5$ $\mathrm{pA}, n=8, p>0.05 ; 100 \mu \mathrm{M}=-48.7 \pm 8$ $\mathrm{pA}$ vs $-45.3 \pm 13.3 \mathrm{pA} n=8 p>0.05$; values measured at $-135 \mathrm{mV}$ ). Furthermore, when L-arginine was added to the bath solution, a significant decrease in $\mathrm{I}_{\mathrm{h}}$ currents was still observed, even in the presence of ODQ $30 \mu \mathrm{M}(-47.6 \pm 14 \mathrm{pA}$ vs $-24.7 \pm 10 \mathrm{pA}, n=5, p<0.05$, at $-135 \mathrm{mV}$ ), suggesting a cGMPindependent effect (Fig. 6).

In view of the results shown above, we asked whether NO could interact with cysteine residues in HCN channels to form S-nitrosothiol complexes. For this purpose, we used NEM to specifically oxidize cysteine residues and avoid S-nitrosylation (Paulech et al., 2013). As shown in Figure 7A, $300 \mu \mathrm{M}$ NEM blocked the effects of L-arginine on instantaneous $\left(\mathrm{I}_{\text {inst }}\right)$ and steady state $\left(\mathrm{I}_{\mathrm{ss}}\right)$ currents $\left(\mathrm{I}_{\text {inst }}=-32.2 \pm 5\right.$ $\mathrm{pA}$ vs $-38.8 \pm 7 \mathrm{pA}, \mathrm{I}_{\mathrm{ss}}=$ control $=-33 \pm 10 \mathrm{pA}, \mathrm{NEM}=$ $-59.2 \pm 15 \mathrm{pA}, \mathrm{L}-\mathrm{Arg}=-59 \pm 11 \mathrm{pA}$, values measured at $-135 \mathrm{mV} ; n=10, p>0.05)$.

Although NEM is a specific cysteine oxidant, it does not remove the NO already linked to cysteine residues. Therefore, ascorbate, a reducing agent, was used to release endogenous NO eventually linked to HCN channels (Stamler and Toone, 2002). As shown in Figure $7 B, B 1$, ascorbate induced a significant increase in the magnitude of both $\mathrm{I}_{\mathrm{h}}$ current components $\left(\mathrm{I}_{\text {inst }}=\right.$ 

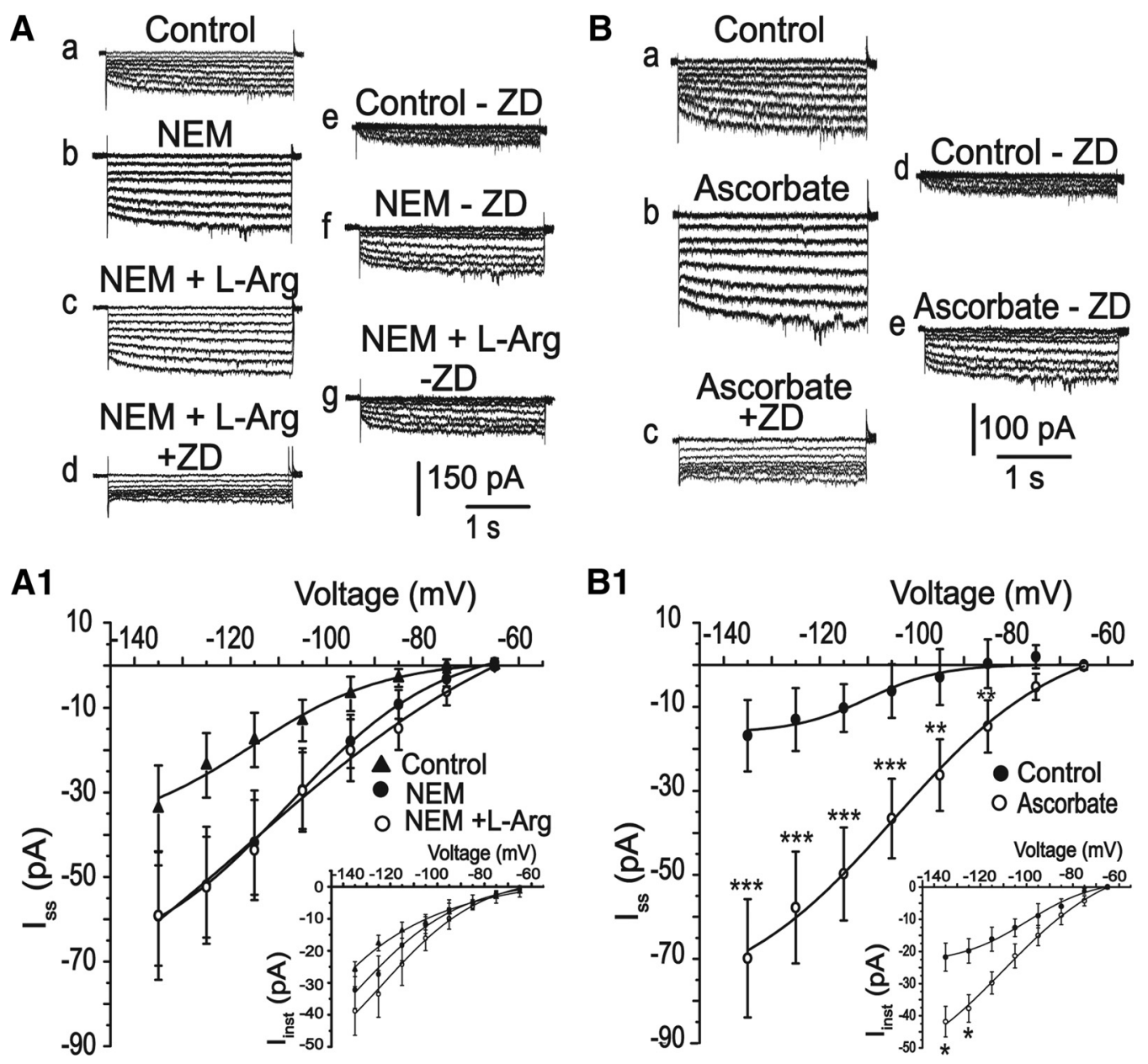

Figure 7. Nitrergic modulation involves S-nitrosylation. $A$, Representative traces of steady-state $I_{h}\left(I_{s s}\right)$ current and instantaneous $I_{h}$ currents $\left(I_{\text {inst }}\right)$ recorded in the control, in the presence of 300 $\mu \mathrm{M}$ NEM, NEM plus L-arginine, and NEM + L-arginine + ZD7288 (30 $\mu \mathrm{M}) . A 1, I-V$ relationships of ZD7288-sensitive currents for each situation. In the presence of NEM, the effects of L-arginine were blocked. $\boldsymbol{B}$, Typical traces of $\mathrm{I}_{\mathrm{h}}$ current activation in three different situations: control ( $\boldsymbol{a}$ ), after $1 \mathrm{~mm}$ ascorbate $(\boldsymbol{b})$, and ascorbate plus ZD7288 (c). $\boldsymbol{d}, \boldsymbol{e}$, Respective $\mathrm{I}_{\mathrm{h}}$ currents. $\boldsymbol{B} \mathbf{1}, \mathrm{I}_{\mathrm{ss}}$ and $\mathrm{I}_{\text {inst }}$ (insets) voltage relationships recorded in control condition and in the presence of ascorbate. Ascorbate induced an increase in both $\mathrm{I}_{s s}$ and $\mathrm{I}_{\text {inst }}$ currents in relation to control. ${ }^{*} p<0.05$ (paired $S t u d e n t ' s t$ test). ${ }^{* *} p<0.005$ (paired Student's $t$ test). ${ }^{* * *} p<0.001$ (paired Student's $t$ test).

$-21.7 \pm 4 \mathrm{pA}$ vs $-41.9 \pm 5 \mathrm{pA}$, at $-135 \mathrm{mV} ; \mathrm{I}_{\mathrm{ss}}=-16.8 \pm 8.5$ pA vs $-69.8 \pm 14 \mathrm{pA}$, at $-135 \mathrm{mV} ; n=6, p<0.05)$. This set of results strongly supports the hypothesis that $\mathrm{NO}$ modulates $\mathrm{HCN}$ channels via an S-nitrosylation-dependent mechanism.

\section{HCN channels are modulated by NO upon osmotic} stimulation

Small changes in plasma osmolality are known to affect vasopressin and oxytocin production and release and also to increase $\mathrm{NO}$ synthesis by the MNCs (da Silva et al., 2013). Therefore, we analyzed whether acute hypertonic or hypotonic challenges can change $\mathrm{I}_{\mathrm{h}}$ currents and whether these responses can be modulated by NO. As shown in Figure 8, hypertonicity increased instantaneous and steady-state $\mathrm{I}_{\mathrm{h}}$ currents in relation to the isotonic situation $\left(\mathrm{I}_{\text {inst }}=-10 \pm 1 \mathrm{pA} \mathrm{vs}-29 \pm 3 \mathrm{pA} ; \mathrm{I}_{\mathrm{ss}}=-20.1 \pm 7 \mathrm{pA}\right.$ vs $-50.3 \pm 9 \mathrm{pA} ; n=8 ; p<0.05$; values measured at $-135 \mathrm{mV})$. Furthermore, an additional increase in $\mathrm{I}_{\mathrm{h}}$ currents was observed during hypertonicity when NO synthesis was blocked by L-NAME $\left(\mathrm{I}_{\text {inst }}=-29 \pm 3 \mathrm{pA}\right.$ vs $-48.3 \pm 3 \mathrm{pA} ; \mathrm{I}_{\mathrm{ss}}=-50.3 \pm 9$ $\mathrm{pA}$ to $-91.7 \pm 14 \mathrm{pA}$; at $-135 \mathrm{mV} ; n=8, p<0.05)$. On the other hand, Figure $8 C$ shows that short-term hypotonic challenge did not change $\mathrm{I}_{\mathrm{h}}$ currents $\left(\mathrm{I}_{\text {inst }}=-18.5 \pm 1 \mathrm{pA}\right.$ vs $-19 \pm 1 \mathrm{pA} ; \mathrm{I}_{\mathrm{ss}}=$ $-40.5 \pm 8 \mathrm{pA}$ vs $-36 \pm 6 \mathrm{pA}$, at $-135 \mathrm{mV}, n=7 ; p>0.05)$.
These data indicate that hypertonicity, but not hypotonicity, acts via $\mathrm{NO}$ to modulate $\mathrm{HCN}$ channels.

\section{Physiological implications of HCN channels function in MNCs}

Because MNC firing frequency is affected by osmotic challenges and determines release of peptides by the neurohypophysis, we used the in situ brainstem-hypothalamus preparation of rats to analyze the physiological role played by HCN channels during acute hypertonic stimulation. For this purpose, the MNC membrane potential was recorded during basal condition, after local infusion of ZD7288 or isotonic ACSF into the SON, followed by perfusion of the preparation with hypertonic ACSF. At the same time, the effusate from the vena cava was collected for radioimmunoassay of VP and OT (for details, see Materials and Methods). As shown in Figure 9, MNC firing rate increased during acute hypertonic perfusion as expected $(3.9 \pm 0.3 \mathrm{~Hz}$ vs $6.3 \pm 0.2$ $\mathrm{Hz}, n=5, p<0.001)$. In addition, the concentration of $\mathrm{VP}$ and OT increased in the effusate $(\mathrm{VP}=1 \pm 0.1 \mathrm{pg} / \mathrm{ml}$ vs $3.2 \pm 0.1$ $\mathrm{pg} / \mathrm{ml}$; OT $=3.59 \pm 0.6 \mathrm{pg} / \mathrm{ml}$ vs $5.3 \pm 0.2 \mathrm{pg} / \mathrm{ml}, n=5, p<$ 0.005 and $p<0.05$ for VP and OT, respectively). On the other side, blockade of HCN channels with ZD7288 decreased MNC firing rate (control $=4 \pm 0.2 \mathrm{~Hz}, \mathrm{ZD} 7288=2.4 \pm 0.1 \mathrm{~Hz}$, 
A

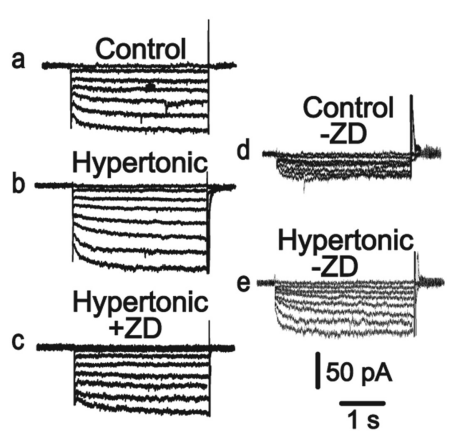

B

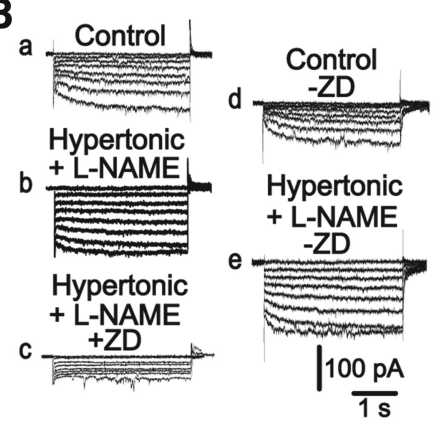

C

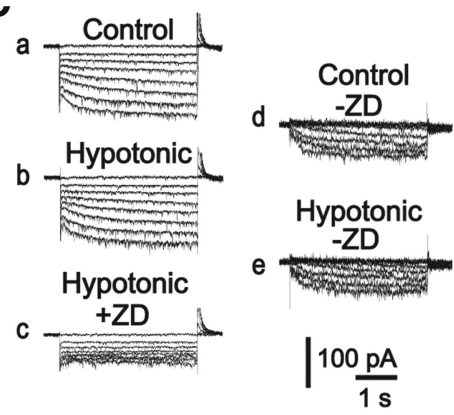

A1

\section{B1}
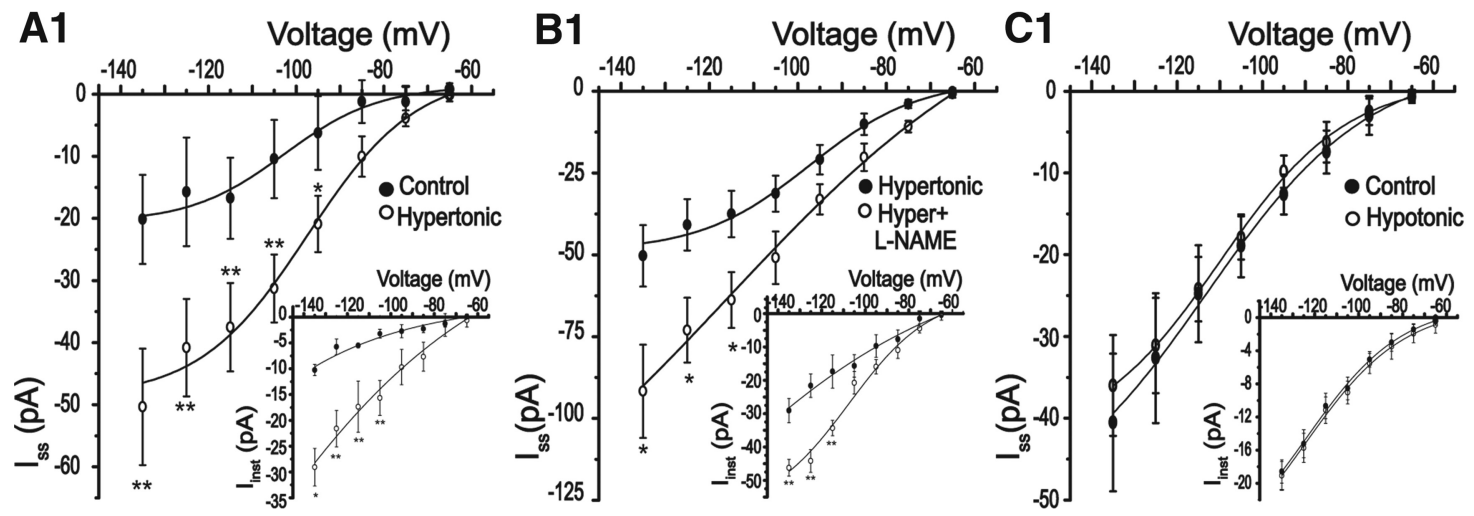

Figure 8. Hypertonicity modulates HCN channels in MNCS. A-C, Typical traces from one neuron in the control (a), during acute hypertonic stimulation (b), hypertonic stimulation plus L-NAME $(\mathbf{B b})$ or hypotonic stimulus $(\boldsymbol{C b})$ followed by $Z D 7288(\boldsymbol{c})$. $\boldsymbol{d}, \boldsymbol{e}, \mathrm{I}_{\mathrm{h}}$ currents for each experimental condition. $\mathbf{A 1}, \mathbf{B 1}, \mathbf{C}$, Average $/-V$ relationships. Acute hypertonicity induced an increase in $\mathrm{I}_{\mathrm{h}}$ current compared with the control. An additional increase was observed when the N0 synthesis was blocked. Hypotonicity did not change the $\mathrm{I}_{\mathrm{h}}$ current. $^{*} p<0.05$ (paired Student's $t$ test). ${ }^{* *} p<0.005$ (paired Student's $t$ test).

Hyper $+\mathrm{ZD}=2.2 \pm 0.1 \mathrm{~Hz} ; n=5$ rats, $p<0.05)$ and prevented $\mathrm{VP}$ and OT release induced by the hypertonic stimulation $(\mathrm{VP}=$ $1 \pm 1.1 \mathrm{pg} / \mathrm{ml}$ vs $1.1 \pm 0.2 \mathrm{pg} / \mathrm{ml}$, OT $=3.8 \pm 0.3$ vs $3.7 \pm 0.5$ $\mathrm{pg} / \mathrm{ml} ; n=5$ rats, $p>0.05)$. These results suggest that HCN channels are critical in determining MNC electrical activity, even in situations where homeostasis is disturbed.

\section{Discussion}

MNCs exposed to long term or acute hypertonicity have their electrical excitability readily modulated by NO (Ventura et al., 2008; da Silva et al., 2013). However, the molecular mechanisms involved in this response were, so far, unknown. Here HCN channels were identified as important players in determining MNC electrical excitability and as targets of nitrergic modulation via a nonconventional signaling pathway, the S-nitrosylation.

\section{Role of $I_{h}$ currents in the control of MNC excitability and NO effects}

Unlike the vast majority, $\mathrm{HCN}$ channels are hyperpolarizationactivated (Wahl-Schott and Biel, 2009) and responsible for carrying an ionic current termed $\mathrm{I}_{\mathrm{h}}$. Our results, using single-cell qRT-PCR, show that the four isoforms of HCN are expressed in the SON, with HCN-3 and HCN-4 mRNAs showing the highest expression levels (Fig. 1). Our data are in accordance with in situ hybridization studies of Monteggia et al. (2000) and of immunohistochemical labeling performed by Notomi and Shigemoto (2004). HCN channels are involved in several basic electrophysiological processes, such as resting membrane potential control, dendritic integration, synaptic transmission, and neuronal electrical oscillations (Maccaferri and McBain, 1996; Gasparini and DiFrancesco, 1997; Beaumont et al., 2002; Fan et al., 2005; Rodrigues and Oertel, 2006). HCN tonic activation places the rest- ing membrane potential at a somewhat depolarized level, whereas their inactivation leads to hyperpolarization (Robinson and Siegelbaum, 2003). Our results, both in slices and in the in situ brainstem-hypothalamus preparation (Figs. 2, 9), show that blockade of HCN channels decreases MNCs spontaneous firing rate and hyperpolarizes the resting membrane potential, in agreement with Ghamari-Langroudi et al. (2000). Similar results are also reported for other excitable cell types (Maccaferri and McBain, 1996; Rodrigues and Oertel, 2006; Deng et al., 2015). In addition, the role played by HCN channels in MNCs seems critical in situations where the hydroelectrolyte homeostasis is disrupted (Fig. 8).

Previous results from our laboratory have shown that NO can modulate MNC resting membrane potential (Ventura et al., 2008; da Silva et al., 2013). Although NO can quickly diffuse from its site of production and interfere presynaptically with GABA release (Stern and Ludwig, 2001), its hyperpolarizing effects are present, even when synaptic transmission is blocked (Ventura et al., 2008; da Silva et al., 2013). Those results point to a direct effect of $\mathrm{NO}$ on the MNCs. Indeed, as shown in Figure 3, NO reduces $\mathrm{I}_{\mathrm{h}}$ current amplitudes by negatively modulating HCN channels. The same result was observed in isolated cells (Fig. 5), strengthening the idea that $\mathrm{NO}$ acts on MNCs independently of synaptic transmission.

$\mathrm{I}_{\mathrm{h}}$ currents are clearly involved in the after-hyperpolarizing potential (HAP) of MNCs and other cell types (Armstrong et al., 1994; Greffrath et al., 1998; Roper et al., 2003; da Silva et al., 2013). HAP sets the firing frequency of neurons by keeping the membrane potential at the appropriate value in relation to threshold for a certain time. Although $\mathrm{MNCs}_{\mathrm{h}}$ currents are of relatively small magnitude $(\sim 30-50 \mathrm{pA})$ they can significantly 
A
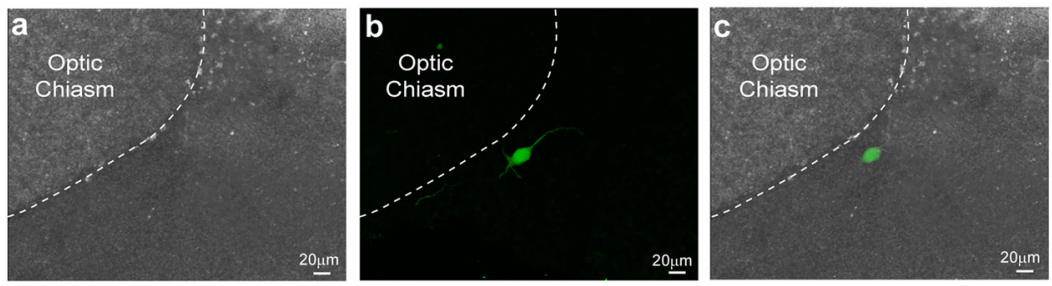

B

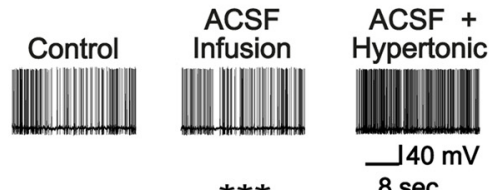

ACSF +

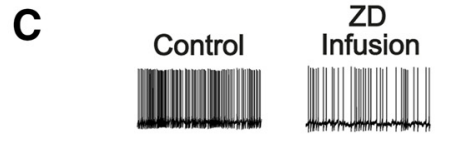

ZD +

B1

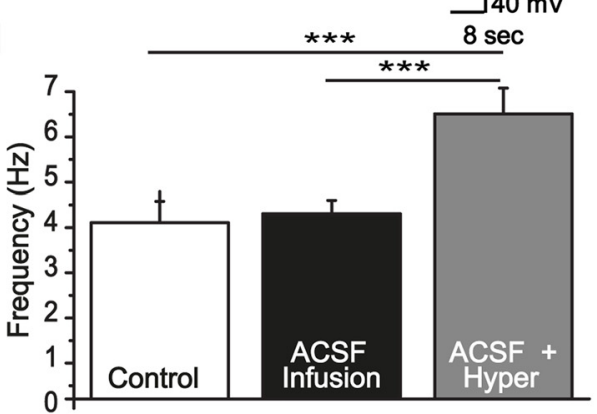

C1
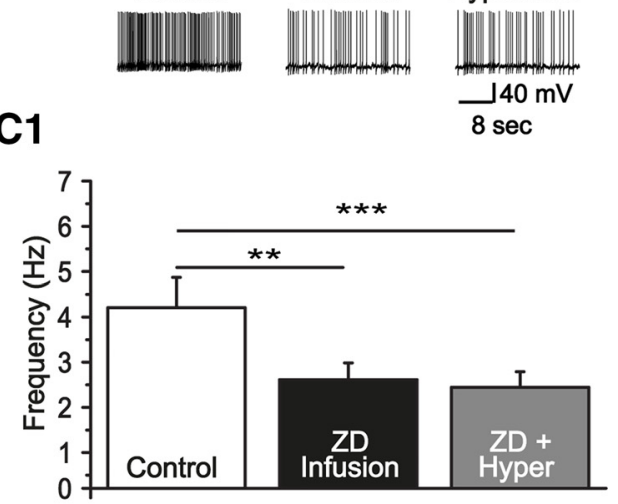

D

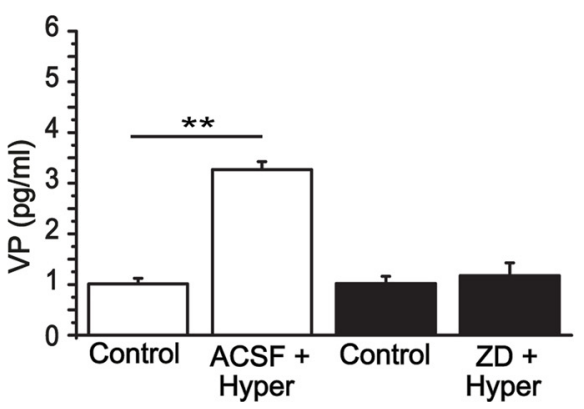

E

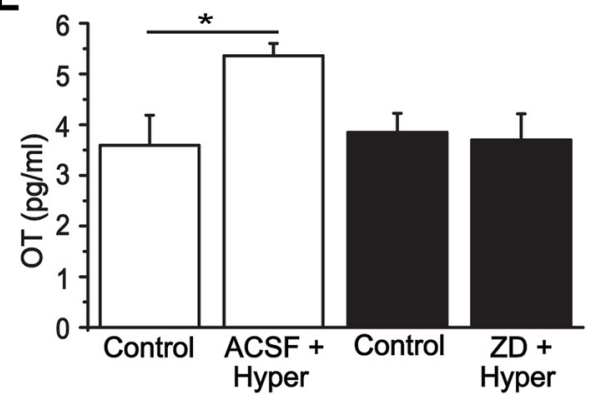

Figure 9. Physiological implications of HCN channel blockade in the SON. A, Immunofluorescence reveals the anatomical localization of neurons recorded using the in situ brainstemhypothalamic preparation: $\boldsymbol{a}$, Bright-field; $\boldsymbol{b}$, biocytin-labeled neuron reveled by streptavidin; $\boldsymbol{C}, \boldsymbol{a}$ and $\boldsymbol{b}$ merged images. $\boldsymbol{B}, \boldsymbol{C}$, Representative traces of two magnocellular neurons recorded in a control condition, after ACSF $(\boldsymbol{B})$ or ZD7288 infusion ( $\boldsymbol{C}$, and hypertonic stimulation (Hyper). $\boldsymbol{B} 1$, Bar graphs are average firing frequencies of neurons recorded during the control, after isotonic $A C S F$ infusion and hypertonic stimulus ( $n=5$ rats). ${ }^{* *} p<0.005$ (ANOVA One Way followed by Bonferroni post hoc test). ${ }^{* *} p<0.001$ (ANOVA One Way followed by Bonferroni post hoc test). ACSF infusion did not change the firing rate of MNCS, and an increase is observed during hypertonic stimulation. C1, Average firing frequencies of neurons in the control condition, after ZD7288 infusion followed by hypertonic stimulation. In this case, previous blockade of $\mathrm{HCN}$ channels avoided the increment in firing rate induced by hypertonicity. $\boldsymbol{D}, \boldsymbol{E}$, Averaged concentrations of vasopressin and oxytocin measured in the effusate, using radioimmunoassay, for each situation. ZD7288 (E) prevented the increase in the concentration of VP and 0 T induced by hypertonicity $(\boldsymbol{D}) .{ }^{*} p<0.05$ (paired Student's $t$ test). ${ }^{* *} p<0.005$ (paired Student's $t$ test).

change the MNCs membrane potential due to the large input resistance observed in these cells $(1.1 \pm 0.5 \mathrm{G} \Omega ; n=12$, data not shown). Therefore, in the absence of this small current, HAP amplitude increases, hyperpolarizing the membrane potential and taking more time to reach threshold and trigger a new action potential. Reinforcing this hypothesis, ZD7288 changed MNCs firing pattern (Figs. 2, 9) similarly to what has been shown by Oswald et al. (2009).

It is also interesting to note that hypertonicity per se was able to increase $\mathrm{I}_{\mathrm{h}}$ (Fig. 8) and to reduce the peak of the HAP (da Silva et al., 2013), both effects leading to increases in the firing rate of neurons. L-NAME enhanced the effect of hypertonicity, indicating that the nitrergic system is actively participating in the control of MNC excitability during osmotic challenges. However, no changes were observed with the hypotonic challenge because there is no NO production above the basal level as shown by da Silva et al. (2013). Therefore, the inhibitory effects of NO on $\mathrm{HCN}$ channels and on the MNC excitability, during hypertonic stimulation, reinforce the hypothesis that $\mathrm{NO}$ is part of a negative feedback mechanism preventing MNC hyperactivity (Liu et al., 1997; da Silva et al., 2013).

\section{NO signaling pathway in the modulation of HCN channels}

NO effects in a number of cell types are mostly due to activation of GC, increasing the synthesis of cGMP and modulation of HCN channels (Bredt and Snyder, 1989; Archer et al., 1994; Zha et al., 2008).

Although MNCs from the SON express both $\alpha 1$ and $\beta 1$ subunits of GC (Furuyama et al., 1993; Koesling et al., 2000; Ding et al., 2004), Southam et al. (1993) demonstrated that cGMP expression in animals perfused with sodium nitroprusside was not detected in MNCs but found in populations of smaller cells and fibers. These results were later confirmed by Vacher et al. (2003). cGMP was found only in GABA, tyrosine hydroxylase, glutamate-positive fibers, as well as in GFAP-stained cells, and was abolished by incubation of the brain slices with L-NAME. Based 
on these facts, it is reasonable to suggest that NO signaling may involve other pathways, such as the covalent binding of $\mathrm{NO}$ to thiol side chains (Qin et al., 2013). NO binds directly to cysteine residues forming nitrosothiol adducts, increasing its availability and modifying the activity of proteins (Mannick et al., 1997; Lang et al., 2000; Ahern et al., 2002). This mechanism was first described for NMDA receptors where cysteine 399 of NR2A subunit can be nitrosylated (Choi et al., 2000). Because there is no specific blocker of S-nitrosylation, here we used NEM to oxidize MNCs cysteine residues, and evaluated whether nitrergic modulation could be explained through this signaling pathway. NEM blocked the effects of L-arginine (Fig. 7), consistent with results in hypoglossal motoneurons (Wenker et al., 2012) showing that NO modulates HCN channels via S-nitrosylation.

Given the diversity and ubiquity of proteins whose function can be regulated by S-nitrosylation (Lander et al., 1997; Lang et al., 2000), its physiological importance cannot be ignored. The advantage of this mechanism can be related to the stability conferred to the NO molecule, which could be stored and transported to long distances in its nitrosylated form. Although binding of NO to cysteine occurs in a covalent way, denitrosylation by S-glutathione, tyrosine nitration, and ascorbate can reverse this interaction (Derakhshan et al., 2007; Benhar et al., 2009). Our results show that ascorbate significantly increased $\mathrm{I}_{\mathrm{h}}$ current amplitudes, implying that HCN channels are endogenously S-nitrosylated (Fig. 7).

\section{Physiological implications}

Physiological responses to changes in the extracellular osmolality must operate synergistically to control salt and water reabsorption by the kidneys. Much evidence indicates that $\mathrm{SON}$ is a central player in these responses due to its ability to sense changes in the extracellular osmolality (Oliet and Bourque, 1992) and to integrate input signals related to the maintenance of hydroelectrolyte balance. Accordingly, during imbalances in osmolality, MNC electrical activity determines the rate of VP and OT release to the circulation (Brimble and Dyball, 1977; Wakerley et al., 1978; Bourque et al., 1994). Here we show that blockade of HCN channels prevented the increase in the release of peptides, even during an acute hypertonic challenge (Fig. 9). Therefore, we can infer that HCN channels, together with other ion channels (Bourque et al., 2002; Zaelzer et al., 2015), are crucial in determining the MNC electrical activity, and that its blockade alters the osmoregulatory mechanisms responsible for the correction of short-term increases in plasma osmolality.

In conclusion, our results show that $\mathrm{NO}$ controls MNC electrical excitability by acting on HCN channels. Furthermore, our results also reinforce the idea that cGMP is not the exclusive mediator of nitrergic modulation: S-nitrosylation is also an important mechanism to control ion channel activity.

\section{References}

Ahern GP, Klyachko VA, Jackson MB (2002) cGMP and S-nitrosylation: two routes for modulation of neuronal excitability by NO. Trends Neurosci 25:510-517. CrossRef Medline

Antunes VR, Yao ST, Pickering AE, Murphy D, Paton JF (2006) A spinal vasopressinergic mechanism mediates hyperosmolality-induced sympathoexcitation. J Physiol 576:569-583. CrossRef Medline

Antunes-Rodrigues J, de Castro M, Elias LL, Valença MM, McCann SM (2004) Neuroendocrine control of body fluid metabolism. Physiol Rev 84:169-208. CrossRef Medline

Archer SL, Huang JM, Hampl V, Nelson DP, Shultz PJ, Weir EK (1994) Nitric oxide and cGMP cause vasorelaxation by activation of a charybdotoxin-sensitive $\mathrm{K}$ channel by cGMP-dependent protein kinase. Proc Natl Acad Sci U S A 91:7583-7587. CrossRef Medline

Armstrong WE, Smith BN, Tian M (1994) Electrophysiological characteris- tics of immunochemically identified rat oxytocin and vasopressin neurones in vitro. J Physiol 475:115-128. CrossRef Medline

Arnold WP, Mittal CK, Katsuki S, Murad F (1977) Nitric oxide activates guanylate cyclase and increases guanosine $3^{\prime}: 5^{\prime}$-cyclic monophosphate levels in various tissue preparations. Proc Natl Acad Sci U S A 74:32033207. CrossRef Medline

Beaumont V, Zhong N, Froemke RC, Ball RW, Zucker RS (2002) Temporal synaptic tagging by $\mathrm{I}(\mathrm{h})$ activation and actin: involvement in long-term facilitation and cAMP-induced synaptic enhancement. Neuron 33:601-613. CrossRef Medline

Benhar M, Forrester MT, Stamler JS (2009) Protein denitrosylation: enzymatic mechanisms and cellular functions. Nat Rev Mol Cell Biol 10:721-732. CrossRef Medline

Biel M, Wahl-Schott C, Michalakis S, Zong X (2009) Hyperpolarizationactivated cation channels: from genes to function. Physiol Rev 89:847885. CrossRef Medline

Bourque CW (2008) Central mechanisms of osmosensation and systemic osmoregulation. Nat Rev Neurosci 9:519-531. CrossRef Medline

Bourque CW, Oliet SH, Richard D (1994) Osmoreceptors, osmoreception, and osmoregulation. Front Neuroendocrinol 15:231-274. CrossRef Medline

Bourque CW, Voisin DL, Chakfe Y (2002) Stretch-inactivated cation channels: cellular targets for modulation of osmosensitivity in supraoptic neurons. Prog Brain Res 139:85-94. CrossRef Medline

Bredt DS, Snyder SH (1989) Nitric oxide mediates glutamate-linked enhancement of cGMP levels in the cerebellum. Proc Natl Acad Sci U S A 86:9030-9033. CrossRef Medline

Brimble MJ, Dyball RE (1977) Characterization of the responses of oxytocin- and vasopressin-secreting neurones in the supraoptic nucleus to osmotic stimulation. J Physiol 271:253-271. CrossRef Medline

Choi YB, Tenneti L, Le DA, Ortiz J, Bai G, Chen HS, Lipton SA (2000) Molecular basis of NMDA receptor-coupled ion channel modulation by S-nitrosylation. Nat Neurosci 3:15-21. CrossRef Medline

Coletti R, Almeida-Pereira G, Elias LL, Antunes-Rodrigues J (2015) Effects of hydrogen sulfide $\left(\mathrm{H}_{2} \mathrm{~S}\right)$ on water intake and vasopressin and oxytocin secretion induced by fluid deprivation. Horm Behav 67:12-20. CrossRef Medline

da Silva MP, Ventura RR, Varanda WA (2013) Hypertonicity increases NO production to modulate the firing rate of magnocellular neurons of the supraoptic nucleus of rats. Neuroscience 250:70-79. CrossRef Medline

da Silva MP, Merino RM, Mecawi AS, Moraes DJ, Varanda WA (2015) In vitro differentiation between oxytocin- and vasopressin-secreting magnocellular neurons requires more than one experimental criterion. Mol Cell Endocrinol 400:102-111. CrossRef Medline

Deng WS, Jiang YX, Han XH, Xue Y, Wang H, Sun P, Chen L (2015) HCN channels modulate the activity of the subthalamic nucleus in vivo. J Mol Neurosci 55:260-268. CrossRef Medline

Denninger JW, Marletta MA (1999) Guanylate cyclase and the.NO/cGMP signaling pathway. Biochim Biophys Acta 1411:334-350. CrossRef Medline

Derakhshan B, Wille PC, Gross SS (2007) Unbiased identification of cysteine S-nitrosylation sites on proteins. Nat Protoc 2:1685-1691. CrossRef Medline

DiFrancesco D (1993) Pacemaker mechanisms in cardiac tissue. Annu Rev Physiol 55:455-472. CrossRef Medline

Ding JD, Burette A, Nedvetsky PI, Schmidt HH, Weinberg RJ (2004) Distribution of soluble guanylyl cyclase in the rat brain. J Comp Neurol 472: 437-448.

Fan Y, Fricker D, Brager DH, Chen X, Lu HC, Chitwood RA, Johnston D (2005) Activity-dependent decrease of excitability in rat hippocampal neurons through increases in I(h). Nat Neurosci 8:1542-1551. CrossRef Medline

Furuyama T, Inagaki S, Takagi H (1993) Localizations of $\alpha 1$ and $\beta 1$ subunits of soluble guanylate cyclase in the rat brain. Mol Brain Res 20:335344.

Gasparini S, DiFrancesco D (1997) Action of the hyperpolarizationactivated current (Ih) blocker ZD 7288 in hippocampal CA1 neurons. Pflugers Arch 435:99-106. CrossRef Medline

Ghamari-Langroudi M, Bourque CW (2000) Excitatory role of the hyperpolarization-activated inward current in phasic and tonic firing of rat supraoptic neurons. J Neurosci 20:4855-4863. Medline

Greffrath W, Martin E, Reuss S, Boehmer G (1998) Components of after- 
hyperpolarization in magnocellular neurones of the rat supraoptic nucleus in vitro. J Physiol 513:493-506. CrossRef Medline

Harris NC, Constanti A (1995) Mechanism of block by ZD 7288 of the hyperpolarization-activated inward rectifying current in guinea pig substantia nigra neurons in vitro. J Neurophysiol 74:2366-2378. Medline

Heid CA, Stevens J, Livak KJ, Williams PM (1996) Real time quantitative PCR. Genome Res 6:986-994. CrossRef Medline

Kase D, Imoto K (2012) The role of HCN channels on membrane excitability in the nervous system. J Signal Transduct 2012:619747. CrossRef Medline

Koesling D, Friebe A (2000) Enzymology of soluble guanylyl cyclase. In: Nitric Oxide (Mayer B, ed), pp 93-109. Berlin: Springer.

Lander HM, Hajjar DP, Hempstead BL, Mirza UA, Chait BT, Campbell S, Quilliam LA (1997) A molecular redox switch on p21(ras): structural basis for the nitric oxide-p21(ras) interaction. J Biol Chem 272:43234326. CrossRef Medline

Lang RJ, Harvey JR, McPhee GJ, Klemm MF (2000) Nitric oxide and thiol reagent modulation of $\mathrm{Ca}^{2+}$-activated $\mathrm{K}+(\mathrm{BKCa})$ channels in myocytes of the guinea-pig taeniacaeci. J Physiol 525:363-376. CrossRef Medline

Liu QS, Jia YS, Ju G (1997) Nitric oxide inhibits neuronal activity in the supraoptic nucleus of the rat hypothalamic slices. Brain Res Bull 43:121125. CrossRef Medline

Livak KJ, Schmittgen TD (2001) Analysis of relative gene expression data using real-time quantitative PCR and the $2(-$ delta delta $\mathrm{C}(\mathrm{T}))$ method. Methods 25:402-408. CrossRef Medline

Maccaferri G, McBain CJ (1996) The hyperpolarization-activated current (Ih) and its contribution to pacemaker activity in rat CAl hippocampal stratum oriens-alveus interneurones. J Physiol 497:119-130. CrossRef Medline

Mannick JB, Miao XQ, Stamler JS (1997) Nitric oxide inhibits Fas-induced apoptosis. J Biol Chem 272:24125-24128. CrossRef Medline

Matulef K, Zagotta WN (2003) Cyclic nucleotide-gated ion channels. Annu Rev Cell Dev Biol 19:23-44. CrossRef Medline

Monteggia LM, Eisch AJ, Tang MD, Kaczmarek LK, Nestler EJ (2000) Cloning and localization of the hyperpolarization-activated cyclic nucleotidegated channel family in rat brain. Brain Res Mol Brain Res 81:129-139. CrossRef Medline

Notomi T, Shigemoto R (2004) Immunohistochemical localization of Ih channel subunits, HCN1-4, in the rat brain. J Comp Neurol 471:241-276. CrossRef Medline

Oliet SH, Bourque CW (1992) Properties of supraoptic magnocellular neurones isolated from the adult rat. J Physiol 455:291-306. CrossRef Medline

Oswald MJ, Oorschot DE, Schulz JM, Lipski J, Reynolds JN (2009) IH current generates the afterhyperpolarisation following activation of subthreshold cortical synaptic inputs to striatal cholinergic interneurons. J Physiol 587:5879-5897. CrossRef Medline

Pape HC (1996) Queer current and pacemaker: the hyperpolarizationactivated cation current in neurons. Annu Rev Physiol 58:299-327. CrossRef Medline

Paulech J, Solis N, Cordwell SJ (2013) Characterization of reaction conditions providing rapid and specific cysteine alkylation for peptide-based mass spectrometry. Biochim Biophys Acta 1834:372-379. CrossRef Medline

Poulain DA, Wakerley JB, Dyball RE (1977) Electrophysiological differentiation of oxytocin- and vasopressin-secreting neurones. Proc R Soc Lond B Biol Sci 196:367-384. CrossRef Medline

Qin Y, Dey A, Daaka Y (2013) Protein s-nitrosylation measurement. Methods Enzymol 522:409-425.

Reis WL, Saad WA, Camargo LA, Elias LL, Antunes-Rodrigues J (2010)
Central nitrergic system regulation of neuroendocrine secretion, fluid intake and blood pressure induced by angiotensin-II. Behav Brain Funct 6:64. CrossRef Medline

Reis WL, Biancardi VC, Son S, Antunes-Rodrigues J, Stern JE (2015) Carbon monoxide and nitric oxide interactions in magnocellular neurosecretory neurones during water deprivation. J Neuroendocrinol 27:111-122. CrossRef Medline

Robinson RB, Siegelbaum SA (2003) Hyperpolarization-activated cation currents: from molecules to physiological function. Annu Rev Physiol 65:453-480. CrossRef Medline

Rodrigues AR, Oertel D (2006) Hyperpolarization-activated currents regulate excitability in stellate cells of the mammalian ventral cochlear nucleus. J Neurophysiol 95:76-87. CrossRef Medline

Roper P, Callaway J, Shevchenko T, Teruyama R, Armstrong W (2003) AHP's, HAP's and DAP's: how potassium currents regulate the excitability of rat supraoptic neurones. J Comput Neurosci 15:367-389. CrossRef Medline

Ruginsk SG, Mecawi Ade S, da Silva MP, Reis WL, Coletti R, de Lima JB, Elias LL, Antunes-Rodrigues J (2015) Gaseous modulators in the control of the hypothalamic neurohypophyseal system. Physiology (Bethesda) 30: 127-138. CrossRef Medline

Southam E, Garthwaite J (1993) The nitric oxide-cyclic GMP signalling pathway in rat brain. Neuropharmacology 32:1267-1277. CrossRef Medline

Stamler JS, Toone EJ (2002) The decomposition of thionitrites. Curr Opin Chem Biol 6:779-785. CrossRef Medline

Stern JE, Ludwig M (2001) NO inhibits supraoptic oxytocin and vasopressin neurons via activation of GABAergic synaptic inputs. Am J Physiol Regul Integr Comp Physiol 280:R1815-R1822. Medline

Vacher CM, Hardin-Pouzet H, Steinbusch HW, Calas A, De Vente J (2003) The effects of nitric oxide on magnocellular neurons could involve multiple indirect cyclic GMP-dependent pathways. Eur J Neurosci 17:455466. CrossRef Medline

Ventura RR, Giusti-Paiva A, Gomes DA, Elias LL, Antunes-Rodrigues J (2005) Neuronal nitric oxide synthase inhibition differentially affects oxytocin and vasopressin secretion in salt loaded rats. Neurosci Lett 379: 75-80. CrossRef Medline

Ventura RR, Aguiar JF, Antunes-Rodrigues J, Varanda WA (2008) Nitric oxide modulates the firing rate of the rat supraoptic magnocellular neurons. Neuroscience 155:359-365. CrossRef Medline

Wahl-Schott C, Biel M (2009) HCN channels: structure, cellular regulation and physiological function. Cell Mol Life Sci 66:470-494. CrossRef Medline

Wakerley JB, Poulain DA, Brown D (1978) Comparison of firing patterns in oxytocin- and vasopressin-releasing neurones during progressive dehydration. Brain Res 148:425-440. CrossRef Medline

Wenker IC, Benoit JP, Chen X, Liu H, Horner RL, Mulkey DK (2012) Nitric oxide activates hypoglossal motoneurons by cGMP-dependent inhibition of TASK channels and cGMP-independent activation of HCN channels. J Neurophysiol 107:1489-1499. CrossRef Medline

Zaelzer C, Hua P, Prager-Khoutorsky M, Ciura S, Voisin DL, Liedtke W, Bourque CW (2015) DeltaN-TRPV1: a molecular co-detector of body temperature and osmotic stress. Cell Rep 13:23-30. CrossRef Medline

Zagotta WN, Olivier NB, Black KD, Young EC, Olson R, Gouaux E (2003) Structural basis for modulation and agonist specificity of HCN pacemaker channels. Nature 425:200-205. CrossRef Medline

Zha Q, Brewster AL, Richichi C, Bender RA, Baram TZ (2008) Activitydependent heteromerization of the hyperpolarization-activated, cyclicnucleotide gated $(\mathrm{HCN})$ channels: role of N-linked glycosylation. J Neurochem 105:68-77. CrossRef Medline 